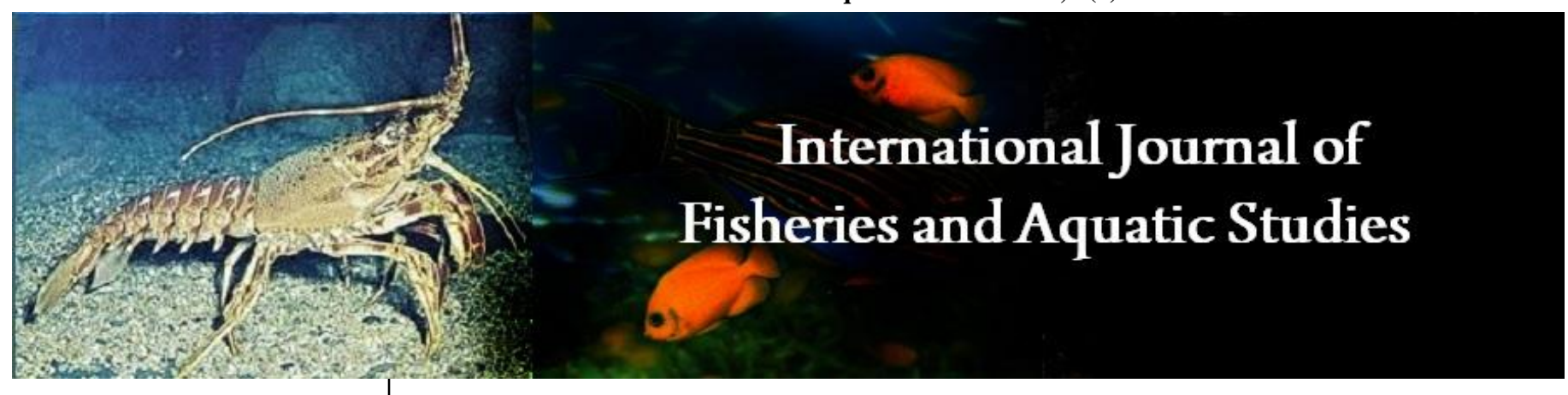

E-ISSN: 2347-5129

P-ISSN: 2394-0506

(ICV-Poland) Impact Value: 5.62

(GIF) Impact Factor: 0.549

IJFAS 2021; 9(1): 18-22

(C) 2021 IJFAS

www.fisheriesjournal.com

Received: 11-12-2020

Accepted: 01-01-2021

Chandravathany Devadason Department of Zoology, Eastern University, Sri Lanka
Corresponding Author:

Chandravathany Devadason

Department of Zoology, Eastern

University, Sri Lanka

\section{Consumer trend and fish distribution in fish markets in Batticaloa district, Eastern Sri Lanka}

\author{
Chandravathany Devadason
}

DOI: https://doi.org/10.22271/fish.2021.v9.i1a.2382

\begin{abstract}
Fish distribution and consumption trends are varied among the people in Sri Lanka. A market and consumer study was conducted to identify the distribution of different fish species in the markets of the district. Moreover a pre-tested questionnaire was employed to collect information on fish consumption behavior and social and cultural factors influencing on fish consumption. Following the purposive sampling technique information were collected from 200 people who came to purchase fish from fish outlets. Results showed that $85 \%$ of the respondents consume fish as their major protein food and $25 \%$ people consumed fish for health purpose. However, all respondents mentioned that fish availability and distribution was the major constraints for consumption of their preferred type of fish. Among the respondents in urban area, approximately $45 \%$ of the respondents preferred seashore fishes (family: clupidae) and $40 \%$ preferred reef fishes (family: Carangidae) and $15 \%$ consume fresh water fishes (family: Cichlidae), but consumption depends on the availability of fish in the respective area and socio economical factors. Distribution of fish in markets showed variation in rural and urban markets. In this line, Shore fish and rock fishes have been distributed in $75 \%$ of the outlets in urban markets and $25 \%$ outlets had the brackish and fresh water fishes while in rural markets distribution of seafishes as $25 \%$ and $75 \%$ was brackish and fresh water fishes.
\end{abstract}

Keywords: Fish, consumption, distribution, market, preference, availability, identification

\section{Introduction}

Fish is major proteinaceous diet to all people in the world and consumption pattern is varied among the people, particularly, Sri Lanka, is an island which is flourished with marine, brackish and fresh water fishes. Fisheries contribute a major share of the GDP of the province (estimated at $15 \%$ in 2007) ${ }^{[4]}$. Fishing is undertaken by $5 \%-6 \%$ of the population of the province as full time and $10 \%-15 \%$ as part time and average production was about 1.2-1.5 metric ton per fisherman per year (NECCDEP report). The fishery of Sri Lanka is almost entirely a coastal one, limited to a relatively narrow belt that extends up to about $60 \mathrm{~km}$ from the shore ${ }^{[4]}$. The fish resource of the coastal waters contributes about $90 \%$ of the total marine fish catch while the offshore and demersal fishery supplies the balance [5]. In 2009 approximately $68 \%$ of fish and fishery products are supplied for the consumption through local production. Although many different types of edible fish are potentially available for consumption, only a relatively small number of species are individually capable of sustaining a large scale fishery ${ }^{[4]}$. The fishery of Sri Lanka is based primarily on the small-scale artisanal fisheries rather than on large scale commercial operations ${ }^{[4]}$. The fish supply is carried by many rural, urban markets and individual sellers. The rural markets receive the fresh fish and shellfish from the fish landing areas of the district itself whereas the urban markets receive fresh and processed (iced) fish from adjoining districts Amparai and Kalmunai. The trend of fish consumption is considerably varied among the community which is highly correlated with Socio-demographics and culture. Fish variety is an important factor in food consumption and consumer try to balance their diet throughout the day (breakfast, lunch and dinner) and across meals over a time span ${ }^{[6]}$. Before deciding what to have for a meal on a particular day, consumers consider the different kind of dimensions such as convenience, price, variety, nutrient, health etc. The availability of marine fish in market is determined seasonally. The Estuarine fish are also highly variable which are migratory fish and in some cases they 
experience large temporal changes in species composition and abundance ${ }^{[9,2]}$. studied the trends and seasonal availability of Marine Food fish at the central market, Kandy, Sri Lanka, stated 84 species of sea fishes belonging to 40 families and the their availability shown varied with season. The objective of the study is to identify the fish distribution and availability in the markets in the Batticaloa district and the preference of fish consumption.

\section{Materials and Methods}

2.1 Location of Markets in district: The study was conducted Batticaloa district, Eastern Province of Sri Lanka, covering the coastal line extending from Kallar to Oddumavadi (Fig 2.1) Preliminary visits was made along the coastal line extending from Kallar to Vakarai to find out availability of markets and the frequency of operation. Of the all the selected market areas, only 12 sites received steady supply of fish and service to local people. However, ten sites were taken to study the distribution of fish and consumer preference and factors deciding the choice of fish on the basis of the availability of markets.

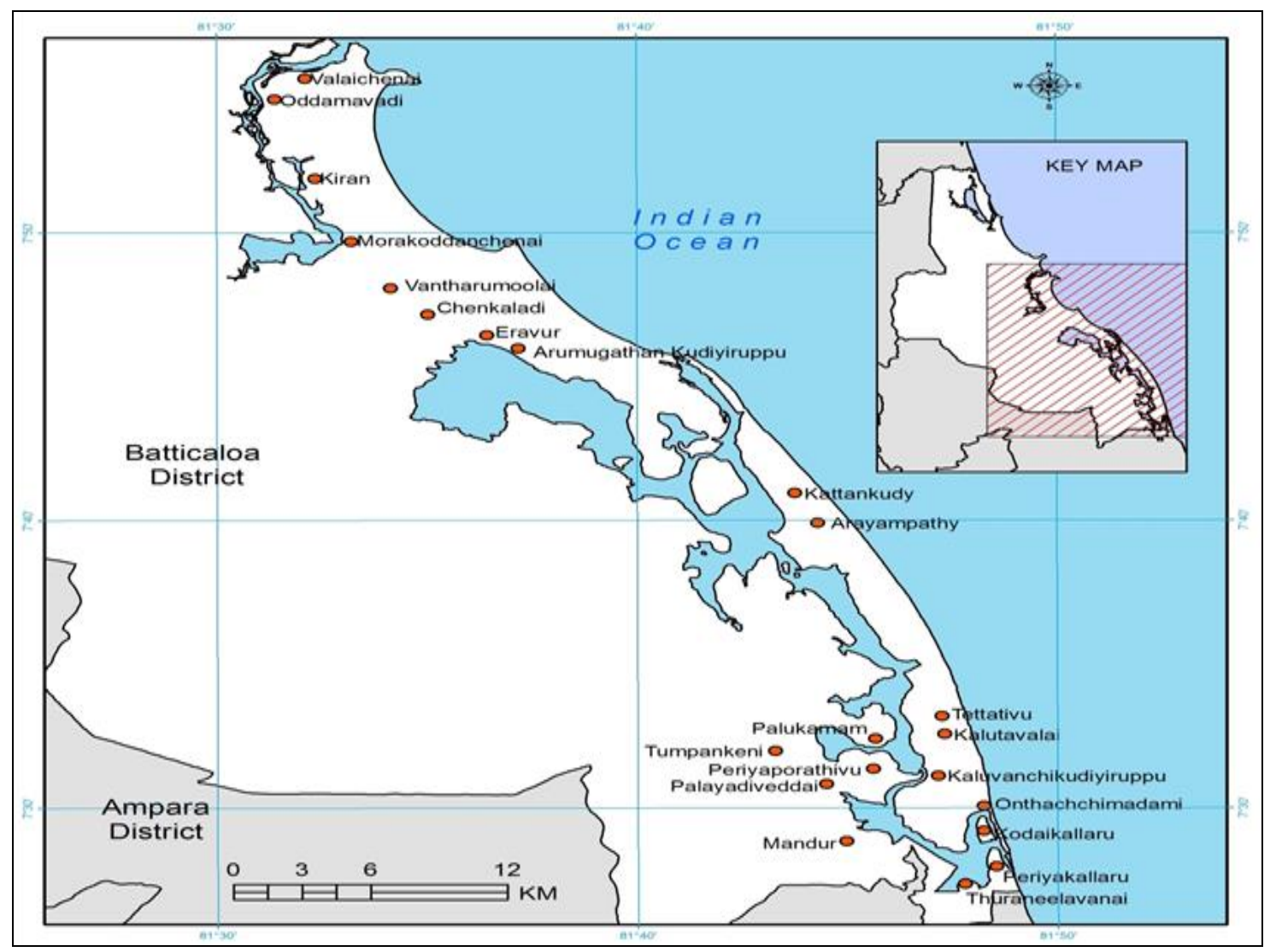

Fig 2.1: Location of Fish Markets in Batticaloa District (Urban and Rural markets)

\subsection{Market survey}

Market survey was carried out in order to find out the availability of fishes. During the preliminary survey availability and different types of fishes like reef fish, seashore fish, lagoon and fresh water fish were recorded. The survey was done twice a month, either first and third weeks or second and fourth weeks of the month using a field survey data sheet. It was conducted for 06 months to cover both dry and rainy seasons. Therefore, 120 market surveys were carried out in the ten markets throughout the study. The information was obtained during peak time between 9-00 am to 12.00 noon from the selected markets. During market surveys, identification fish done using the key of ${ }^{[3,7]}$. In addition interviews were carried out with the consumers and suppliers of fish without interrupting sales. Some of the interviews were carried out in their houses of the sale persons as per their request.

\subsection{Identification of Fishes}

Preliminary identification of the fishes was done with the help of local names called by sale person and with the fish keys and texts ${ }^{[7,3]}$. All food fish species were identified in family and most of them were identified at species level. Some of the fishes which were new species to Sri Lanka and those were identified using keys (Australian and Western Pacific). The vernacular name (Tamil and Sinhala) were also noted from the experienced fishers and sale persons and the photograph of the fish species were taken at the market and used to identify.

\subsection{Availability of Fish Variety}

The availability of given variety of fish at a stall in terms of approximate numbers was recorded.The data from all the stalls were pooled to obtain a measure of availability, in terms of an abundance rating based on number of fish and denoted as $* * *$ (highly abundant or $>75 \%$ ), ** (moderately abundant or $25-75 \%)$ and $*($ scarce or $<25 \%)$.

\subsection{Occurrence of fishes during market survey}

Frequency occurrence of fishes (reef, seashore and brackish and fresh water) was noted in family level. Total number of occurrence of each fish variety was recorded from 120 visits of 10 markets survey. Frequency of occurrence of each fish variety in family level and species level were calculated as follows. Frequency of occurrence of fishes was calculated as follows: 


$$
\begin{aligned}
& \text { Frequency of Occurrence }(\%)=\frac{\text { Number of times a given fish (family level) occur } \times 100}{\text { Total number of visits (200) }} \\
& \text { Overall Market Availability of fishes }(\%)=\frac{\text { One type of fish (Family) in each market x100 }}{\text { Total number of fish (family) in each market }}
\end{aligned}
$$

\subsection{Fish Consumption pattern among local community.} Consumers ("subjects') of the fish were interviewed at the time of purchasing of fish. A preliminary semi-structured questionnaire was prepared and it was pre-tested in a sample of 150 individuals randomly. Random sampling technique was used to select the subjects. Interviews were carried out with the semi-structured questionnaire. Because of limitation of time during marketing some of the interviews were continued in their houses too. The interviews were mainly focused on the types and purpose of consuming the fishes as freshed form, or preserved form whether reef fishes or sea shore fishes and brackish and fresh water fishes. Choice of fish in market was interviewed in respect of nutrition, prize, good for health, medicinal purpose, external appearance and fatty nature.

\section{Results and Discussion}

The total of 65 families of bony fishes have been identified in ten urban and rural markets. The occurrence of fish in markets showed varying with season (Fig 3.4.). The families which included reef fish, shore fish and lagoon fishes. Among reef fishes, Carangidae (jacks or carangids) family (100\%) in different species were available in all seasons in urban markets (Fig.3.1) whereas in shore fishes Clupidae (sardines $\&$ herrings) family (100\%) was available in all seasons in the rural markets as shown in the fig.3.1. Next to the Carangidae, Lethrinidae (emperors) family showed the available in markets which were seen abundant during January to March in both urban and rural markets (Fig,3.1). Consumers preference was focused in selection of reef fishes, Carangidae, Sphyrenidae (barracudas)and Lethrinidae respectively which were noted in urban markets whereas in rural markets shore fish Clupidae and Leonathidae (pony fish) were preferred fish species by consumers. However, in both markets, shore fish species were abundant and preferred fish by consumers( fig.3.2). When the abundant of fish were observed, the carangidae and clupidae family were abundant in all seasons with different species (Fig 3.4.). Some species of Carangidae and clupidae were seen throughout study period as seen in Fig 3.4 .

As per the overall availability of fish in markets showed in
Fig 3.3 it is varying with the location of markets where urban markets showed high percentage of Carangidae and the rural markets showed Clupidae. In both markets, Clupidae, Ciclidae, Chirocentridae (ribbon fish) and Belonidiae (needle fish) were seen. The available of fish in the market is determined by location of the market and the nature of consumers as it was recorded from the consumers'survey. Consumers who belong middle income and above family showed preference on reef fishes belong to Carangidae, Lethrinidae and Sphyrenidae families where as low income families showed preference on the shore fishes like Clupidae, Leonathidae, Chirocentridae and Ciclidae. As far the abundant of fish variety is determined with season. Fishes belong to Carangidae, Clupidae, Leonathidae, Ciclidae and Lethrinidae in different species were seen in both dry and rainy season where was some families like Caesionidae (fusiliers) and Holocentridae were seen abundant during dry seasons, other families particularly, Engraulidae (ancovy), Lutijanidae (sapan) were seen abundant during rainy season seen in Fig 3.3. Availability of fish in the market is seemed to correlate with many factors including culture and population dynamics. Choice of fish in market is also determined based on the availability of fish in the market. From the survey, 30 $\%$ people told about taste and nutrition and $20 \%$ people said the prize is prime concern and none of the people said about the appearance of fish would decide the choice of fish. Nevertheless, all people who interviewed said that the quality and freshness are main factor for selecting fish to buy. ${ }^{[2]}$ stated that Scombridae, Carangidae and the Clupeidae were abundant in all seasons in the Market of Kandy which received the fish from different part of the island where as the markets in Batticaloa districts receive fish from district itself and adjoining districts. However, the different species in Clupeidae family are found throughout the season in urban and rural markets (fig3.3). It is concluded that the different species in Carangidae family is found in all urban markets throughout of the year whereas the Ciclidae is found abundantly in rural markets and the consumer preference is based on the availability and quality and prize of fish as Tilapia sp belong to ciclidae family are multispawner and throughout the year can be harvested as stated by ${ }^{[8]}$.

Table 3.1: Commonly seen Reef fishes and Shore fishes in the Urban markets

\begin{tabular}{|c|c|c|c|c|}
\hline Carangidae & Signaidae & Sphyraenidae & Serranidae & Scombridae \\
\hline Caranx para & Siganus canaliculatus & Sphyraenea jello & Epinephelus undulosus & Rastreliger kanagurata \\
\hline Carangoides ferdau & Siganus stellatus & Sphyraene obtusata & Ephinephalus coioides & Thunnus abesus \\
\hline Caranx melampygus & Signaus vermiculatus & Spyraena barracuda & Ephinephelus bleekeri & Katsuwonus pelamis \\
\hline Caranx papuensis & Signaus lineatus & Sphyraenea forsteri & Ephinephelus chlorostigma Scomberomorus commersoni \\
\hline Ganathanodon speciosus & Siganus Javas & Lethrinidae & Epinephelus tauvina & Hamulidae \\
\hline Ganathanodon speciosus & Lutijanidae & Lethrinus obsoletus & Cephalopholis sexmaculata & Plectorhinchus schotaf \\
\hline Carangoides chrysophrys & Lutjanus ehrenbergii & Lethrinus olivaceus & Ephinephalus merrs & Pomadasys multimaculatum \\
\hline Carangoides gymnostethus & Lutjanus vitta & Lethrinus nebuloses & Cepahlopholis sonnerati & Holocentridae \\
\hline Scomberoides tol & Lutijanus russeli, & Lethrinus mahsena & Ephinephelus lanceolatus & Myripristis melanostictus \\
\hline Elegatis bipinnulata & Lutjanus argentimaculatus & Lethrinus ornatus & Sianidae & Sarcocentron diadema \\
\hline Carangoides caeruleopinnata & Lutjanus johnii & Lethrinus ruprioperculatus & Nibea albida & Sargocentron rubrum \\
\hline Carangoides caeruleopinnata & Lutjanus quinquelineatus & Lethrinus nebuloses & Nibea maculata & Belondiae \\
\hline Carangoides plagiotaenia & Pristipomoides typus & Lethrinus lentjan & Johnius belangerii & Tylosurus crocodilus \\
\hline Carangoides malabaricus & Lutjanus madras & Lethrinus conchyliatus & Argyrosormus amoyensis & Strongylura leiura \\
\hline Carangoides fulvogutiatus & Pristopomoides multidens & Lethrinus semicinctus & Nibea soldado & Trichiuridae \\
\hline Scomberoides commersonianus & Lutijanus monostigma, & Hemirambidae & Johnuius macrorhynus & Lapturacanthus savala \\
\hline
\end{tabular}




\begin{tabular}{|c|c|c|c|c|}
\hline Scomberoides tala & Lutijanus laminiscatus & Hemirampus lutkeri & Otolithes cuvieri & Scatophagidae \\
\hline Coryphaenidae & Lutjanus rivulatus & Hypohampus dussumieri & Johnius vogleri & Scatophagus argus \\
\hline Coryphaena hippurus & Lutjanua sepae & Hyporhampus limbatus & Otolithes rube & Ephippidae \\
\hline Chirocentridae Chirocentrus dorab & Aprion viresens & $\begin{array}{c}\text { Rynchorcampus } \\
\text { malabaricus }\end{array}$ & & Ephippus orbis \\
\hline
\end{tabular}

Table 3.2: Commonly seen Shore and Inland fishes

\begin{tabular}{|c|c|c|c|c|}
\hline Clupidae & Leiognathidae & Engraulididae & Cichilidae & Centroporinidae \\
\hline Anodontosoma chacunda & Leiognathus bindus & Stolephorus commersoni & Orecochromis niloticus & Cephalopholis aurantia \\
\hline Nematalosa nasas & Leiognathus lineolatus & Stolephorus indicus & Oerchocromis mozambica & Latus calcarifer \\
\hline Tenualosa toli & Gazza achlamys & Stolephrous waitei & Tilapia sp & Psammoperca waigensis \\
\hline Hilsa kelee & Secuator insidiator & Thryssa hamiltonii & Etroplus maculatus & Gerridae \\
\hline Amblygaster sirm) & Secutor rugonius & Thryssa striostris & Etroplus suratensis & Gerres oyena \\
\hline Sardinella albella & Leiognathus brevirostris & Thryssa purava & Mugilidae & Gerres filametosus \\
\hline Amblygaster clupeoides & Leiognathus dussumieri & Exocoetidae & Liza macrolepis & Gerres abbreviatus \\
\hline Amblygaster leogaster & Leiognathus blochi & Crypselurus oligolepis & Mugil cephalus & Pentaprion longimanus \\
\hline Sardinella gibbosa & Leiognathus fasciatus & Exocoetus volitans & Liza melinoptera & Gerres lucidus \\
\hline Sardinella longiceps & Leiognathus daura & Parexocetus mento & Anabantidae & Gerres oblongatus \\
\hline Dussumieria acuta & Leognathus smithurst & Cyprinidae & Anabas testudineus & Teraponidae \\
\hline Tenualosa ilisa & Gazza minuta & Cirrhiuns cirrhosus & Chanidae & Terapon puta \\
\hline Escualosa thoracata & Leiognathus Leuciscus & Labeio rohita & Chanus chanus & Terapon jarpuva \\
\hline Sardineel fumbriata) & Ambassidae & Puntius chola & Plotosidae & Drapnidae \\
\hline Sluridae & Ambassis gymnocephalus & Sillaginidae & Plotosus lineatus & Drepane punctata \\
\hline Wallago attu & Elopidae & Silago sihama & Plotous Canius & Echenidae \\
\hline & Elops machnata & & & Echeneis naucrates \\
\hline
\end{tabular}

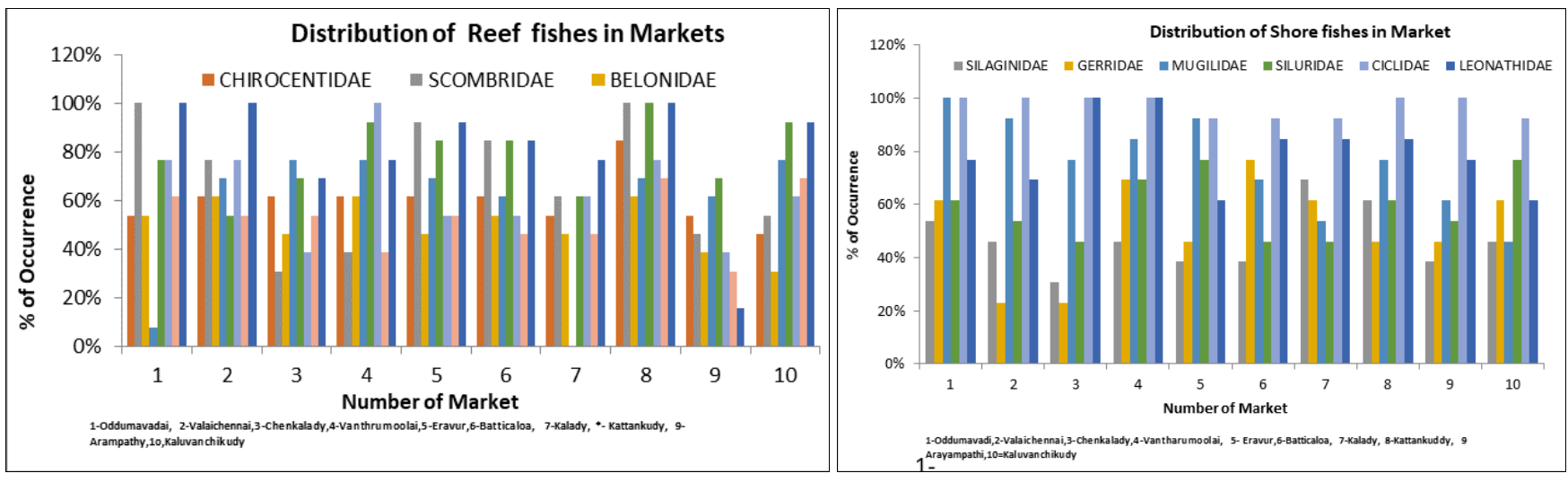

Fig 3.1: Distribution of shore and reef fishes in urban and rural markets

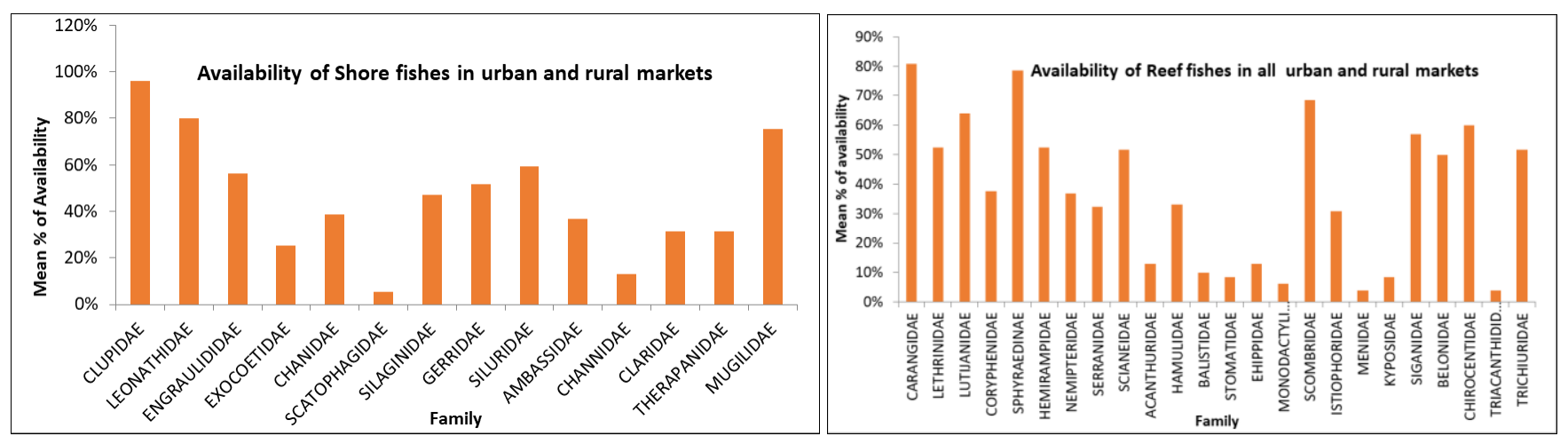

Fig 3.2: Availability of Shore line and Reef fish (family) in Urban and Rural Markets 


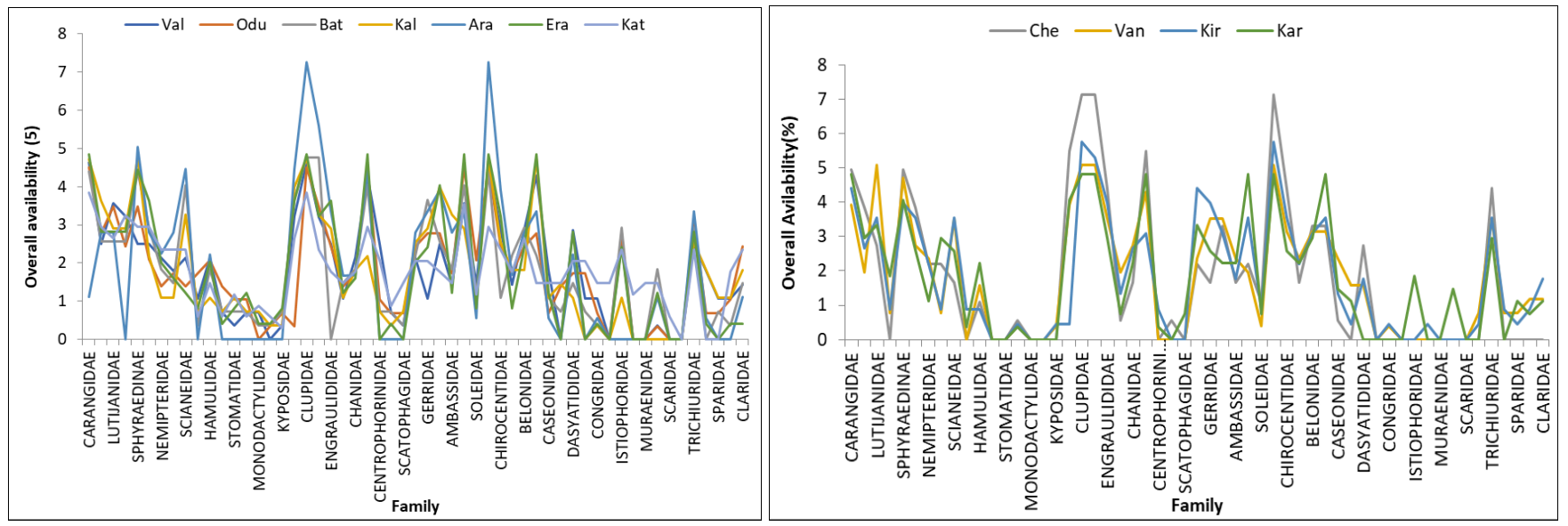

Fig 3.3: Overall fish availability $(\%)$ in Urban (L)and Rural(R) markets, Here, Val-Valichennai, Odu-Oddumavadi, Bat-Batticaloa, KalKaluvanchikuddy, Ara-Arampathy, Era-Eravur, Kat-Kattankuddy, Che-Chenkalady, Van-Vantharumoolai, Kir-Kiran, Kar-Kalar.

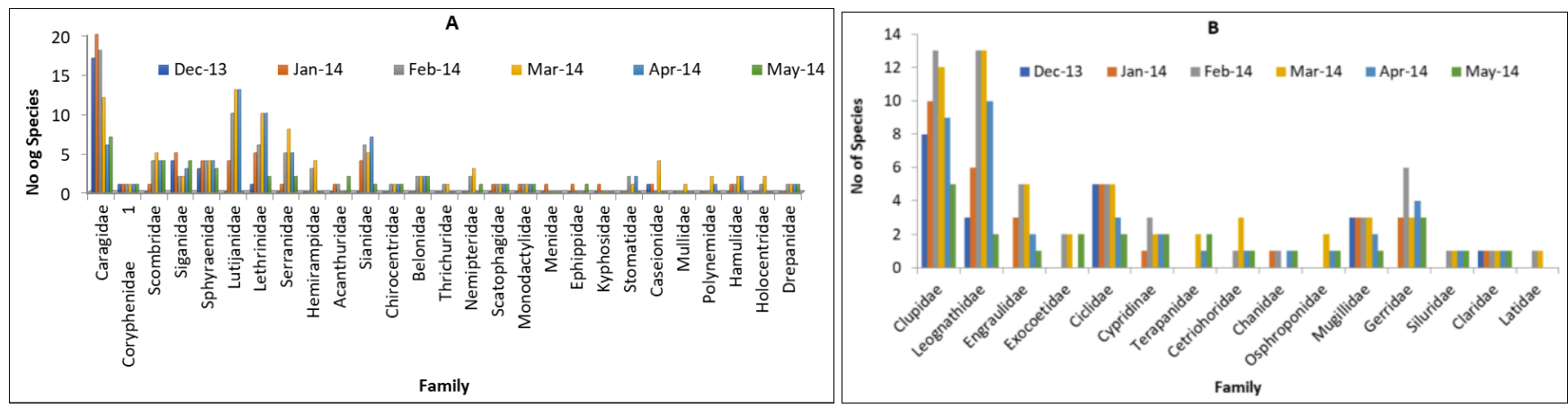

Fig 3.4: The A and B graph shows the number of Reef fish species and Shore and Inland fish species respectively vary with the season (Dec13 to May 14).

\section{Acknowledgement}

I acknowledge my supervisors who supervised my research and Eastern University, Sri Lanka for provided grant.

\section{References}

1. Carpenter KE. FAO Species Catalogue. Volume 8, Fusilier Fishes of the World, FAO Fisheries Synopsis, 1988;125(8):75.

2. De Silva DN. Trends in Seasonal Availability of Marine Food Fish at the Central Market, Kandy, Sri Lanka, Sri Lanka, Journal of Aquatic Science 1997;2:95-109.

3. De Bruin GHP, Russell BC, Bogusch A. The Marine Fishery Resources of Sri Lanka, FAO species identification field guide for fishery purposes. Rome, 1994.

4. NARA. Fisheries Out look National Aquatic Research Agency; Sri Lanka 2018.

5. Jinadasa. A review of the marine fin fish fisheries research in Sri Lanka from Vidyodaya Journal of Science 1902-1990,1991(a);3:1-21.

6. Meiselmen HL, Johnson JL, Reeve W, Crouch JE. Demonstrations of the influence of eating environment on food acceptance, Appetite 2000;35(3):231-237.

7. Munro ISR. The Marine and Freshwater of Ceylon, 1955. Department of External Affairs, Canberra.

8. Philippart JCl, Ruwet JCI. Ecology and distribution of tilapias. In: R.S.V. Pullin and R.H. Lowe McConnell (eds.). The biology and culture of tilapias. ICLARM Conf. Proc 1988;(7):15-60.

9. Tremain MD and Adams DH. Seasonal variations in species diversity, abundance and composition of fish communities in the northern Indian river lagoon, Florida
Bulletin Marine Science 1995;57(1);171-192. 